\title{
Release of The Rights on Management of PT. Indonesian Port III, (Persero) To The Certificate of Land And Building Connected to Marine Tourism Village in Semarang
}

\author{
M. Ali Mashar ${ }^{1}$ and Akhmad Khisni
}

Abstract. Land is a natural resource that is essential for human survival. But this time the land is a natural resource that is finite and diminishing. Land has many proprietary someone (private) and state-owned land has been extremely limited. Based on the background mentioned above have been presented, the authors are interested to examine, discuss and review the above issues in the form of a study entitled: " Release Of The Rights On Management Of PT. Indonesian Port III, (Persero) To The Certificate Of Land And Building Connected To Marine Tourism Village In Semarang". The results are expected to contribute ideas for the development of legal science in particular on how the waiver process management PT. Indonesian Port III, The method used is qualitative analysis. Based on the formulation of the problem it is concluded HPL release the legal basis must be based on legislation, if not yet published legislation, it can be subjected to a government regulation to replace legislation or government regulation (a regulation). HPL release law committed by PT. Pelindo on land certificates are fully controlled by people of Tambak Lorok so that the transition will not happen obstacles.

Keywords: Release; Right On Management; PT. Indonesian Port III (Persero); Semarang.

\section{Introduction}

Land is a natural resource that is essential for human survival. But this time the land is a natural resource that is finite and diminishing. Land has many proprietary someone (private) and state-owned land has been extremely limited. Land issues closely related to humans as the fulfillment of their needs for survival. For Indonesian people and the land rights of existing objects above it is an important law, but if it is really necessary to do this right of revocation and exemption for development purposes.

Thus the use, possession, and use of land for life and human life needs to be arranged so as to create order in social life. Given the land into an object that is prone to dispute, because the human need for land is increasing but the supply of land is relatively fixed. As a source of life, the existence of land in people's lives have meaning and also has dual functions as a Social Asset and Capital Asset. Social Asset ground as a means of binding unity among the community's social life and life, while as the Capital Asset land is a capital factor in development and has grown as a very important economic objects. ${ }^{3}$

The conception of the National Law of Land called Comunalistic religious, which allows control of land individually with rights on the ground of personal nature, such as the

\footnotetext{
1 Master of Notary's Student Sultan Agung Islamic University (UNISSULA) Semarang email maulanaalimashar.87@gmail.com.

${ }^{2}$ Lecture of Faculty of Law UNISSULA

3]ayadi Setiabudi 2012 Tata Cara Mengurus Tanah. Rumah Serta Segala Perizinannya Pustaka Kasih Jakarta hlm.4.
} 
Property Rights, which also contains a social function as an element of togetherness as may be inferred from the provisions of Article 1 (1) BAL were set the ground rights Indonesian nation, connected with the provisions of Article 4, Article 6 and Article 16 paragraph (1) BAL governing rights over the land. Property Rights to Land in Indonesia Article 16 of the Basic Agrarian Law (BAL) to determine the types of land rights, which include: Properties, leasehold, Right to build, rights to use, rights to rent, Rights of Opening the Land, Picking rights of Forest Products.

BAL in determining the kinds of land rights are open, meaning BAL still open opportunities to the addition of new land rights other than those specified in Article 16 paragraph (1) BAL. BAL is the juridical basis for the regulation of land issues in Indonesia. Rights Management (HPL) is not set explicitly in the BAL, BAL only in the General Explanation Romawai II explained that: "The state can give the land to or giving something Ruler Agency (Department, Bureau, or the Autonomous Region) to be used for the implementation of the respective duties respectively. Maria SW Sumardjono stated that management rights are not rights to land but is part of the State's Rights which most authority delegated to management rights holders. ${ }^{4}$

Management rights to land are often referred to as HPL. Rights Management birth is not based on law but based on the Agricultural Ministerial Regulation No. 9 of 1965 On the State's implementation of a conversion rights and provisions of Wisdom Next. Regulation is the first using the term for the Management, as referred to in Article 2 of Regulation of the Minister of Agrarian No. 9 of 1965, which specifies that, "if the state land as referred to in Article 1, in addition to be used for the benefit of the agencies themselves, intended also to be given with something right.

Right Management is the Right to Control of State authority delegated to the holder partial implementation, among others, Government Agencies including Local Government, State-Owned Enterprises, Regional Owned Enterprises, PT.Persero, Authority and statutory bodies of other governments to be used for the execution of their duties each.

HPL holder has authority to hand over the land to a third party to Indonesian citizens and legal entities entities established under Indonesian law and domiciled in Indonesia. Management Rights Holders authorities hand over portions of land management rights to a third party for a while. Delivery of parts of land management rights Rightsholders management to a third party for a time in the travel by means of an agreement between the Rightsholders land use management with third parties. ${ }^{5}$

Management Rights Holders authorities hand over portions of land management rights to a third party for ever. Delivery of parts of land management rights Rightsholders management to a third party for ever not reached by way of land use agreements. Rather reached by way of the release or transfer of rights management by the rights holder. Third party acquire portions of land management rights from the release or transfer of rights management is proprietary. ${ }^{6}$

Based on the background mentioned above have been presented, the authors are interested to examine, discuss and review the above issues in the form of a study entitled: " Release Of The Rights On Management Of PT. Indonesian Port III, (Persero)

\footnotetext{
4 Maria SW Sumardjono 2009 Tanah Dalam Perspektif Hak Ekonomi Sosial Dan Budaya Kompas Jakarta p. 213

${ }^{5}$ Urip Santoso Hukum Agraria Kajian Komprehensif Kencana Jakarta p. 193

${ }^{6}$ Ibid p. 199
} 
To The Certificate Of Land And Building Connected To Marine Tourism Village In Semarang".

Based on the description and background of the above problems, the authors are interested to discuss the issue further with emphasis on the problem of how implementation of Waiver Stewardship PT. Indonesian Port III Against the Certificate of Property Rights to Land and Buildings In Marine Tourism Village in Semarang and How Legal Certainty Ownership Certificate of Property Rights to Land And Building Post-Implementation Waiver Stewardship PT. Indonesian Port III

\section{Research methods}

The data obtained are arranged systematically, and then analyzed qualitatively to achieve clarity issues to be discussed. The data is then analyzed using a theoretical and interpretive positive law which has been poured and then deductively conclude to address existing problems.

\section{Discussion}

\subsection{Marine Tourism Village in Semarang}

Tambak Lorok Village is the largest fishing villages in the city, that is located in the Javanese Sea coastline. The village is located just on the outskirts of the northern city of Semarang directly adjacent to the waters of the Javanese Sea, exactly on the edge of the River Banger. Administratively, this region is part of the village of Tanjung Mas, North Semarang. Region with an area of 84.48 ha \pm is divided into two areas, namely region Mulyo Pond to the west and Tambak Rejo in the east.

In 2018 the population reached 10.503 peoples. Most residents have Tambak Lorok livelihood as fishermen, merchants, small industries, cottage industries related to fishing. This area is a densely populated area located close to the sea. Not when floods are making this area submerged, tidal water also makes the settlement condition is getting worse. Residents living on the edge of the sea, also have to face the high waves. Some walls of their homes were damaged by the waves hit. The buildings house most low due to decreased land so it is prone to floods and abrasion. Under such conditions, the inhabitants had to elevate his house regularly every few years so that their homes do not drown. Facilities and infrastructure in the region is quite to fill, but the environmental conditions in the region according to the authors do not meet the health aspects, the preservation of life, ecology and climate. As a result of lack of attention to these aspects then the resulting impression rundown on site. Therefore, it is necessary to improve the quality Tambak Lorok region through the realignment of settlement to resolve the above problems, and a tourist village, which is able to support the community's economy Tambak Lorok. For sustainability efforts settlements in the region required careful planning area and is able to solve problems on their own Lorok pond. The government is already planning the construction of the fishing village of this region. In this plan there is construction of flats.

\subsubsection{Release Implementation}

Tambak Lorok area management plan implemented after the Semarang city government obtain certain rights to management of these areas. Previous region there 
is the issue of dual status, between HPL PT Indonesian Port III Properties Limited and certificate on behalf of the citizens Tambak Lorok. And, that problem has been a problem in the area management. Since January 14, 2015, PT Pelindo has approved the release of Land Management Rights (HPL) with a number of letters PJ.06 / 19 / TMS-2015. Later, the region will officially become the property of the citizens, and the development and management can be done by the city government. Although the release is still in the process of the Land Office of Semarang, but it has become a bright spot for the planned growth in the Maritime Region Tambak Lorok.

\subsubsection{Remove the Land}

Regional rejuvenation concept approach in line with the national program of Housing and Planning Regions Slums. It also supports the Maritime Development program, so it will be a regional maritime Tambak Lorok region. General Manager of PT Pelindo III branch Tanjung Emas, Tri Suhardi said it had agreed in principle with the status double relinquish the land with total area of 26 hectares. With details on Rejomulyo 21.7 hectares and 4.3 hectares in Tambakrejo, District of North Semarang. It was agreed on instructions from the Ministry of SOE. He said that, at this time the right to the land release process to wait on the National Land Agency (BPN). Later status of Land Management Rights (HPL) PT Pelindo III branch Tanjung Emas and ownership rights (HM) residents will be separated. In the document the land is still double the status and still no notes and letters of PT Pelindo III. The principle is to take off the ground it is no problem for the appropriate instructions from the Ministry of BUMN, Tri explained that according to Port Master Plan (RIP) Tanjung Emas, HPL in Sub Rejomulyo and Tambakrejo planned for development of the port. Thus, the land of HPL which is outside that has been released, will still be used for the benefit of the Port of Tanjung Emas.

The procedure for the implementation of land managing waiver of the ownership certificate of land and buildings. Granting individual is granting rights to a plot of land to an individual or a particular legal form or to some person or legal entity to collectively as the assignee jointly conducted with the determination of entitlements. Request Properties on the State Land submitted in writing include:

- Information about the applicant: name, age, nationality, place of residence and work well as a description of the wife / husband and children are still dependents;

- Description of the land that includes juridical and physical data:

Basic tenure or pedestal rights can be a certificate, girik, letters of plots, paperwork proof of waiver and settlement of land and house or land that has been purchased from the government, court decisions, certificates PPAT, deed of waiver, and mail proof other land acquisition, location, boundaries and extent (if any Measure Letter or Picture situation mentioned dates and numsber); The type of land (agricultural / nonagricultural); land use planning; Status of the land (state land or land rights) Other: Information on the number of fields, spacious and status of lands owned by the applicant, requested ternasuk plot; Other information deemed necessary. Request Properties enclosing a copy of a letter identity, proof of citizenship of the republic of Indonesia.

Procedures for Property Rights submitted to the Minister through the Chief of the Land Office that the area of work includes the lay of the land in question. After the file is accepted, Head Office and researching the Land Checking data completeness juridical and physical data; Noting the entry form; provide a receipt file a request, notify the 
applicant to pay the costs necessary to complete the request with the details in accordance with the provisions of the legislation in force.

If all requirements have been met, then the decree was issued granting rights and these rights must be registered with the local land agency office in order to obtain strong evidence of these rights as certificates. Thus, it is understood that the land rights can not be provided solely by concessionaires, but must be proposed to the agency / competent authority according to the procedure and the conditions that have been set. However, in practice, concessionaires carry out their own entitlement to a third party without the right registration, even entitlements in the form of lease rights, as occurred during the port land use agreement. In fact, as arranged, that the rights management can not be granted the right to lease the land.

\subsection{Legal Certainty Ownership Certificate of Property Rights to Land And Building Post-Implementation Waiver Stewardship PT. Indonesian Port III}

Indeed HPL is one of the basic rights that come from the country's constitution article 33, paragraph 3 UUDN RI 1945: "The earth, and water, and natural riches contained therein controlled by the state and used for large to prosperous of the people. In the village of Tambak Lorok, HPL which has been initiated since 1992 while the company that has HPL is PT. Pelindo then result in ownership certificates owned Tambak Lorok became disabled citizens in terms of legal or illegal under holdings in BPN but also owned by PT. Pelindo which resulted in all transactions relating to the certificate of transfer of rights of citizens to be blocked.

As a result of the release of HPL law committed by PT. IPC against citizen ownership certificate is a letter or certificate of land being entirely controlled by people of Tambak Lorok so that the transition will not happen obstacles.

\section{Closing}

\subsection{Conclusion}

- The legal basis for the release of HPL should be based on legislation, if not yet published legislation, it can be subjected to a government regulation to replace legislation or government regulation.

- HPL release law committed by PT. Pelindo on land certificates are fully controlled by society Tambak Lorok so that the transition will not happen obstacles.

\subsection{Suggestion}

Associated with some of the problems it is by this authorproviding advice as follows:

- The government should make strict rules regarding management rights. Where these rules are not only regulated in the Regulation of the Head of BPN, but regulated in the Law for the Rights issue.

- Management is an issue that concerns the interests of the community. 


\section{References}

[1] Jayadi Setiabudi 2012 Tata Cara Mengurus Tanah. Rumah Serta Segala Perizinannya Suka Buku Jakarta

[2] Maria S.W. Soemardjo 2008 Tanah dalam perspektif Hak Ekonomi sosial dan budaya Kompas Jakarta

[3] Urip Santoso 2012 Hukum Agraria Kajian Komprehensif Kencana Jakarta

[4] Regulation of the Minister of Agrarian / BPN No. 9 of 1999 Procedures Pemeberian and cancellation of state land rights and management rights

[5] Minister of State for Agrarian Affairs / Head of National Land Agency No. 3 of 1997 on the Implementation of PP No.24 / 1997. 